\title{
PROFIL VERTIKAL KANDUNGAN OKSIGEN TERLARUT DAN FLUORESEN IN VIVO SEBAGAI INDIKATOR KEBERLANGSUNGAN KEHIDUPAN DI PERAIRAN LAUT MALUKU DAN LAUT SULAWESI
}

\author{
VERTICAL PROFILES OF DISSOLVED OXYGEN AND \\ IN VIVO FLUOROSCENCE AS MARINE LIFE INDICATOR \\ IN MALUKU SEA AND SULAWESI SEA
}

\author{
Iis Triyulianti ${ }^{1,3}$, Indra Hermawan ${ }^{2,3}$, Agung Yunanto ${ }^{1}$, Novia Arinda Pradisty ${ }^{1}$, \\ Aditya Chandra Raymonza ${ }^{3}$, Fikrul Islamy ${ }^{1}$, Nadia Christa Magdalena ${ }^{1}$ \\ 'Balai Riset dan Observasi Laut, BRSDMKP, Bali. \\ ${ }^{2}$ Pusat Riset Kelautan, BRSDMKP, Jakarta \\ ${ }^{3}$ INDESO Project Team \\ e-mail : iisyulianti19@gmail.com
}

Diterima tanggal: 14 Februari 2017 ; diterima setelah perbaikan: 7 Juli 2017 ; Disetujui tanggal: 31 Juli 2017

\begin{abstract}
ABSTRAK
Kegiatan pelayaran Indeso Joint Expeditions (IJEP) 2016 melakukan pengukuran in situ beberapa parameter kualitas air, salah satunya oksigen terlarut serta biomass fitoplankton yang terekspresikan dari nilai fluoresen in vivo. Kedua parameter diukur untuk menganalisis komponen penting dalam siklus biogeokimia laut dengan menggunakan metode titrimetrik dan pemanfaatan sensor optik. Ekspedisi IJEP 2016 berlangsung dari tanggal 5-15 September 2016 menempuh jalur dari pelabuhan atau dermaga P2LD-LIPI Ambon hingga Pelabuhan Bitung, Sulawesi Utara dengan mengambil 19 titik stasiun pengukuran dan pengambilan sampel air di perairan Laut Maluku dan Laut Sulawesi. Hasil pengukuran in situ kandungan oksigen terlarut dengan metode titrasi menunjukkan variasi baik secara horisontal dan vertikal yang diukur pada 7 lapisan kedalaman $(10,50,60-150,300,500,750$ dan 1000 meter). Distribusi oksigen terlarut secara vertikal pada 19 stasiun penelitian menunjukkan bahwa konsentrasi oksigen berkurang seiring dengan bertambahnya kedalaman dengan kisaran nilai 3,334 - 7,321 mg/L. Penurunan konsentrasi oksigen terlihat mulai lapisan permukaan hingga kedalaman di atas lapisan termoklin (50 - 400 meter). Kandungan oksigen berkurang setelah kedalaman maksimum kandungan klorofil yang terekspresikan dari nilai fluoresen in vivo dengan kisaran antara $0,4441-1,1376 \mathrm{mg} / \mathrm{m}^{3}$ pada kedalaman yang berbedabeda. Konsentrasi oksigen terlarut lebih tinggi baik secara vertikal dan horizontal di perairan Laut Sulawesi di banding Laut Maluku pada musim peralihan (September 2016). Kondisi sebaliknya terjadi pada profil konsentrasi fluoresen in vivo yang memiliki konsentrasi lebih tinggi di perairan Laut Maluku. Pengaruh massa air internal permukaan yang berasal dari Laut Banda terhadap tingginya konsentrasi fluoresen in vivo terukur di perairan Laut Maluku terlihat pada hasil penelitian ini. Hasil pengukuran konsentrasi oksigen terlarut dan fluoresen in vivo baik secara vertikal dan horisontal mengindikasikan bahwa Laut Maluku dan Laut Sulawesi memiliki daya dukung ekosistem yang cukup baik untuk menjaga keberlangsungan kehidupan didalamnya.
\end{abstract}

Kata kunci: Oksigen terlarut, fluoresen in vivo, Laut Maluku, Laut Sulawesi, klorofil.

\section{ABSTRACT}

Indeso Joint Expeditions Cruise (IJEP) activity in 2016 measured some water quality parameters, two of them are dissolved oxygen and in vivo fluorescence for expressing biomass of phytoplankton community. Those parameters were measured for analyzing the important component of marine biogeochemical cycle by using titrimetrik method and optical sensor. Expedition of IJEP was conducted on September 5-15, 2016 starting from port of P2LD-LIPI Ambon into Bitung port, North Sulawesi. Measurement results of Dissolved Oxygen (DO) at 21 stations showed varied values vertically and horizontally. Vertical distribution of $D O$ and in vivo flouresence were measured at seven layer of depth water (10, 50, 60-150, 300, 500, 750 and 1000 meter). Distribution of DO decreased during ocean inventory with values range between was 3,334 - 7,321 $\mathrm{mg} / \mathrm{L}$. Depletion of dissolved oxygen from surface layer into the upper of termocline layers (50-400 meter). Concentration of DO decreased after chlorophyll maximum layer (represent as in vivo fluorescence) at different layer of water depth with values range between 0,4441 - 1,1376 mg/m3. The concentration of dissolved oxygen were higher both vertically and horizontally in Sulawesi Sea than in Maluku Sea at this transtitional season (September 2016), but inversely condition for the in vivo flouresence which is higher in Maluku Sea. There was an indication of internal upper water mass impacts on the

Profil Vertikal Kandungan Oksigen Terlarut dan Fluoresen in vivo sebagai Indikator Keberlangsungan Kehidupan di

Perairan Laut Maluku dan Laut Sulawesi - Iis Triyulianti, Indra Hermawan, Agung Yunanto, Novia Arinda Pradisty, Aditya Chandra Raymonza, Fikrul Islamy dan Nadia Christa Magdalena 
highest concentration of in vivo flurosence in Maluku Sea. These results indicate that Maluku Sea and Sulawesi Sea have good enough carrying capacity of ecosystem for suistainability of their marine life.

Keywords: Dissolved Oxygen, in vivo Flouresence, Maluku Sea, Sulawesi Sea, Chlorophyll.

\section{PENDAHULUAN}

INDESO (Infrastructure Development of Space Oceanography) adalah proyek pengembangan sistem prakiraan operasional oseanografi yang dilakukan untuk memantau proses sirkulasi biogeokimia dan perikanan wilayah peairan Indonesia. Proyek ini dikembangkan sebagai pusat prakiraan dan pengelolaan sumber daya laut yang dapat memberikan prediksi perubahan-perubahan pada sumber daya perikanan dan ekosistem pesisir di Indonesia. Komponen utama dari proyek INDESO meliputi: (1) Pemodelan numerik, (2) Pusat sistem informasi dan (3) stasiun bumi penerima data satelit radar di Perancak, Bali. Pengembangan model numerik fisika dan biogeokimia perairan Indonesia pada proyek INDESO ini didukung oleh pengambilan data lapangan melalui sebuah pelayaran ilmiah Indonesia timur yang diberi nama Indeso Joint Expedition Cruise (IJEP) pada bulan September 2016.

Kegiatan pelayaran ilmiah melalui IJEP cruise 2016 dilakukan untuk pengukuran dan pengambilan sampel air bagi kepentingan analisis parameter fisika, kimia dan biologi di perairan Laut Maluku dan Laut Sulawesi. Laut Maluku dan Laut Sulawesi sebagai bagian perairan Indonesia Timur memiliki peranan yang strategis bagi aktivitas perikanan, pelayaran serta peranan ekologis di wilayah Indonesia Timur. Lokasi penelitian pada pelayaran ilmiah atau cruise IJEP tahun 2016 ini merupakan bagian dari wilayah penangkapan perikanan (WPP) 714, 715 dan 716. Wilayah Penangkapan Perikanan (WPP) 714 meliputi perairan Teluk Tolo dan Laut Banda merupakan kesatuan ekosistem laut dengan ciri khas perairan laut dalam pada wilayah perairan teritorial (pheripheral deep sea). Paduan karakteristik khas perairan ekosistem laut menghasilkan kondisi oseanografi sangat dinamis dan secara hidrografis memberikan sifat-sifat ekologis yang sangat menguntungkan bagi habitat ikan pelagis terutama ikan Tuna dan Cakalang (Suman et al., 2014).

Oksigen terlarut merupakan salah satu komponen dasar kebutuhan organisme perairan serta keberadaanya meregulasi beberapa proses biologi dan kimia (Brown, et al., 2005). Senyawa oksigen merupakan senyawa yang terkait langsung dengan karbon melalui peristiwa fotosintesis dan respirasi (Stramma et al., 2008 and Keeling et al., 2010). Keberadaan atau profil konsentrasi oksigen di wilayah ekosistem perairan merupakan cermin bagi konsentrasi dan profil sebaran nutrient seperti yang dinyatakan oleh Brown et al. (2005). Laju konsentrasi oksigen pada kolom perairan terkait dengan karbon melalui proses fotosintesis dan respirasi sebarannya di kolom perairan membentuk stratifikasi hingga kedalaman $1 \mathrm{Km}(1000 \mathrm{~m})$ yang disebut juga lapisan oksigen minimum atau zona oksigen minimum (Brown et al., 2005; Paulmier \& Ruiz-Pino., 2011). Distribusi vertikal atau profil vertikal konsentrasi oksigen di kolom perairan hingga mencapai kedalaman oksigen minimum, salah satunya didukung oleh proses fisika oseanografi seperti kejadian adveksi dan percampuran vertikal (vertical mixing) seperti yang dinyatakan oleh Pearson et al. (1978).

Keberadaan oksigen terlarut pada kolom perairan merupakan produk proses biologi yang akan mempengaruhi secara langsung kehidupan akuatik khususnya respirasi aerob, pertumbuhan dan reproduksi (Brown et al., 2005). Konsentrasi oksigen akan menggambarkan seberapa besar perairan menerima beban bahan organik tanpa menyebabkan gangguan bagi organisme hidup. Produsen oksigen terlarut dalam kolom perairan adalah fitoplankton melalui proses fotosintesis yang membutuhkan cahaya matahari serta klorofil-a untuk mengubah senyawa karbon anorganik terlarut menjadi karbon organik terlarut dengan melepaskan oksigen (Falkowski \& Raven, 2007). Fitoplankton merupakan mikrorganisme penting di perairan karena tidak hanya menyediakan oksigen namun juga sebagai penyedia karbon organik bagi organisme pada tingkatan trofik yang lebih tinggi (Higher Trophic level). Perubahan yang terjadi pada variabel karbon dan oksigen pada suatu ekosistem laut terkait dengan perubahan faktor lingkungan lainnya seperti suhu dan nutrient berpengaruh terhadap fungsi sistematik dan sinergik organism laut (Cocco et al., 2013) tidak terkecuali fitoplankton.

Salah satu metode yang digunakan untuk mengukur biomassa fitoplankton adalah dengan mengukur konsentrasi atau biomassa klorofil (Mackey et al., 2000) secara in situ. Pengukuran konsentrasi klorofil secara kontinyu menggunakan klorofil in vivo pertama 
kali dikembangkan oleh Lorenzon (1966) dengan memodifikasi model III Turner fluoremeter di laut, karena fluoresen dan klorofil berkorelasi positif sehingga dapat digunakan untuk memonitor konsentrasi klorofil secara kontinyu pada nilai kisaran 0,04 - 15 $\mathrm{mg} / \mathrm{L}$ untuk ekosistem laut.

Observasi laut pada pelayaran ilmiah IJEP 2016 mengukur konsentrasi oksigen terlarut serta fluoresen in vivo untuk memberikan gambaran kondisi terkini mengenai sebaran atau distribusi melalui profilnya di kawasan perairan Laut Maluku dan Laut Sulawesi yang merupakan Wilayah Penangkapan Perikanan (WPP) 714, 716 dan 717 sehingga dapat diketahui kualitas perairan dalam menopang kehidupan laut di lokasi tersebut. Informasi dan pengetahuan mengenai kondisi hidro oseanografi di kawasan perairan ini masih belum banyak, sehingga dalam tulisan kali ini akan dibahas juga mengenai nilai suhu, salinitas dan densitas terukur untuk mengetahui karakteristik massa air yang melintasi perairan tersebut. Hasil penelitian ini diharapkan dapat memberikan informasi dan pengetahuan terbaru sehingga diharapkan dapat bermanfaat bagi penelitian sejenisnya yang masih minim di wilayah ini di masa yang akan datang.

\section{BAHAN DAN METODE}

\section{Waktu dan Tempat penelitian}

Penelitian dilakukan pada kawasan perairan Laut Maluku dan Laut Sulawesi yang membentang pada lintang $4^{0} \mathrm{LU}-4^{0} \mathrm{LS}$ dan $120^{\circ} \mathrm{BT}-128^{\circ} \mathrm{BT}$ (Gambar 1) pada tanggal 5 - 15 september 2016 menggunakan kapal penelitian Baruna Jaya VIII. Selama pelayaran melakukan pengukuran parameter fisika, kimia dan biologi oseanografi pada 19 titik stasiun sekaligus air sampel untuk dilanjutkan analisisnya di Laboratorium Kualitas Perairan, Balai Riset dan Observasi Laut (LKP-BROL), Jembrana, Provinsi Bali.

Perairan Laut Maluku dan Laut Sulawesi merupakan kawasan perairan Indonesia Timur yang dilintasi oleh arus lintas Indonesia (ARLINDO) dari Samudera Pasifik pada lapisan intermediate (Tomsczak \& Godfrey, 2003). Secara geografis Laut Maluku terletak di barat Samudera Pasifik dan membatasi Laut Sulawesi di Utara dan Laut Banda di Selatan serta masih termasuk wilayah Provinsi Maluku. Laut Sulawesi juga terletak di barat Samudera Pasifik dibatasi oleh Kepulauan Sulu, Laut Sulu dan Pulau Mindanao, Filipina di Utara, rangkaian kepulauan Sangihe di Timur, Selatan dengan Sulawesi dan barat dengan Kalimantan, Indonesia.

\section{Metode Pengukuran dan Pengambilan Sampel Air (Sampling)}

Pengukuran parameter hidro-oseanogarfi (suhu, salinitas dan densitas) menggunakan CTD (Conductivity, Temperature, Depth) SEA BIRD ELECTRONIC SBE911(CTD911) yang diintegrasikan dengan Niskin rosette bottle sample bervolume 10 Liter dalam satu frame.

Pengukuran menggunakan CTD (CTD casting) pada setiap stasiun yang telah ditentukan dapat diketahui profil suhu, salinitas, densitas maupun khlorofil-a melalui nilai fluoresen in vivo setiap CTD diturunkan lalu perekaman data dan pengambilan air sampel dilakukan pada saat CTD naik. Penentuan lapisan kedalaman pengambilan air sampel dilakukan dengan melihat profil suhu, salinitas dan klorofil, dimana ditentukan tujuh (7) lapisan pengambilan air sampel untuk mewakili lapisan permukaan (upper layer), intermediate (thermocline layer), dan lapisan dingin (dalam/deep layer). Tujuh lapisan kedalaman pengambilan sampel tersebut adalah 10-20, 50-75, 100$150,500,500,750,1000$ meter dengan memperhatikan kedalaman maksimum klorofil untuk menentukan pengambilan sampel di atas lapisan termoklin Keakuratan hasil pengukuran suhu, konduktivitas dan tekanan dengan menggunakan sensor pada CTD SBE911 adalah sebesar $0,001 \pm 0,0002^{\circ} \mathrm{C}, 0,0003 \pm 0,00004$ $\mathrm{S} / \mathrm{m}$ dan tekanan adalah $0,015 \pm 0,001 \%$.

Konsentrasi kandungan oksigen terlarut (Dissolved Oxygen) diukur dengan metode titrasi (potensiometrik) Winkler mengikuti standar pengukuran internasional (Carritt \& Carpenter, 1966). Estimasi konsentrasi oksigen dengan metode Winkler dilakukan pada air sampel dari tujuh lapisan kedalaman pengambilan air sampel yang berbeda, sedangkan secara kontinyu pengukuran juga dilakukan dengan sensor oksigen yang terintegrasi pada CTD sehingga terjadi pengukuran langsung saat CTD turun dan di rekam datanya saat CTD naik.

Sensor optik fluoresen in vivo untuk mengukur klorofil terintegrasi dengan alat CTD sehingga pengukuran dan perekaman data dapat secara langsung saat casting CTD.

\section{Analisa Data}

Hasil pengukuran CTD berupa suhu, salinitas dan densitas dianalisis untuk menjelaskan pergerakan massa air yang melintasi wilayah studi serta karakteristik hidro

Profil Vertikal Kandungan Oksigen Terlarut dan Fluoresen in vivo sebagai Indikator Keberlangsungan Kehidupan di 


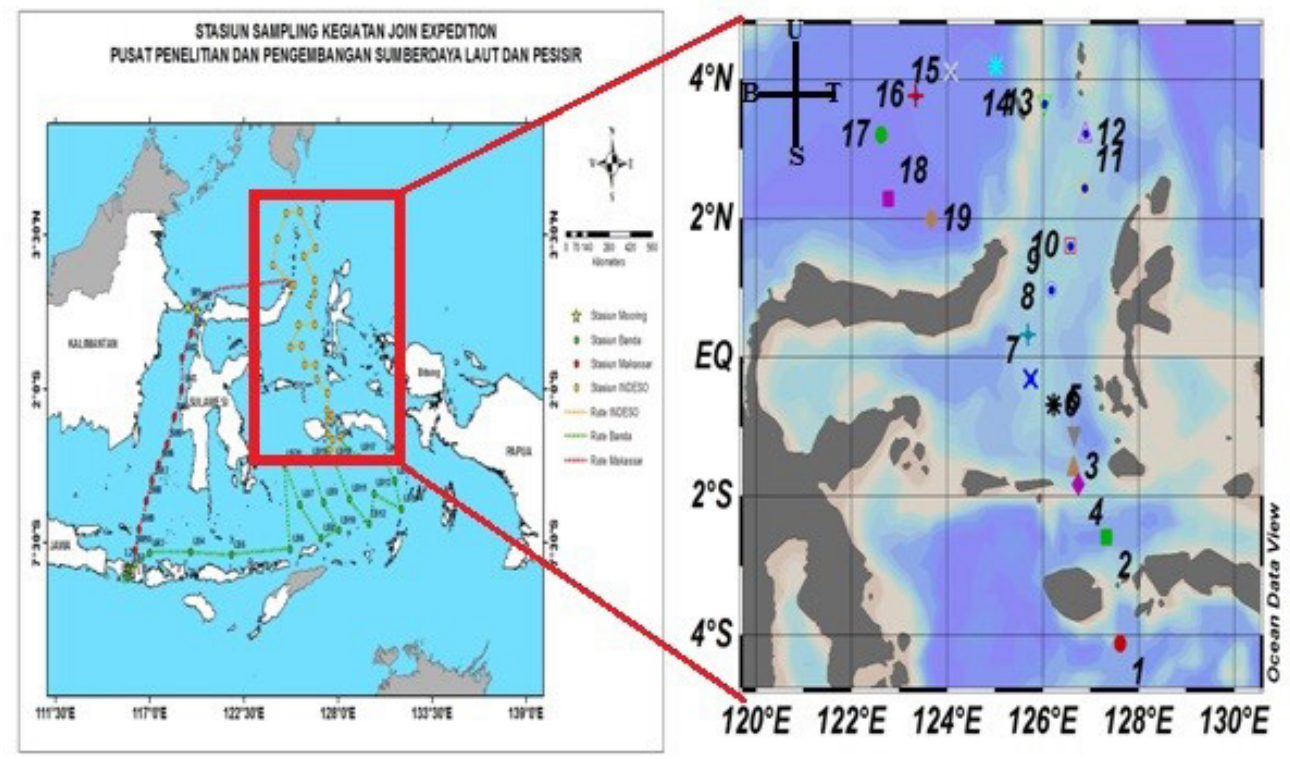

Gambar 1. Peta lokasi penelitian serta posisi stasiun pengukuran dan pengambilan sampel cruise IJEP 2016.

Figure 1. Location map of research and position of IJEP 2016 cruise measurement and sampling station.

oseanografinya. Massa air yang melintasi wilayah studi dapat diketahui dari informasi yang digambarkan oleh diagram suhu potensial dan salinitas (T-S diagram), hal ini sangat penting dilakukan karena lokasi penelitian merupakan salah satu bagian perlintasan ARLINDO (Indonesian Throughflow) dari Samudera Pasifik. Untuk mengetahui konsentrasi oksigen terlarut dan fluoresen in vivo pada kedua lokasi penelitian yaitu Laut Maluku dan Laut Sulawesi dibuat pola sebaran horisontal dan vertikal untuk memperlihatkan profilnya. Analisis dilakukan dengan mendeskripsikan dari pola sebaran atau profil vertikal dan horisontal untuk parameter yang diamati. Pembuatan grafik dan gambar diagram, dibantu dengan menggunakan software Ocean Data View versi 4.5.6 (Schlitzer, 2014).

\section{HASIL DAN PEMBAHASAN}

\section{Data Hidro-Oseanografi}

Keseluruhan stasiun pengukuran (Gambar 2.A) merupakan kawasan perairan dalam dengan kontur berbeda-beda, kedalaman maksimum pengukuran parameter fisikia dan kimia perairan dengan sensor yang terintegrasi pada CTD hanya mencapai kedalaman 1100 meter. Profil suhu dan salinitas permukaan (kedalaman 1-10 meter) pada musim peralihan ditunjukkan pada Gambar 2 C\&D. Hasil pengukuran yang dilakukan di bulan September 2016 menunjukkan bahwa wilayah perairan Laut Sulawesi memiliki suhu lebih hangat dan salinitas yang lebih tinggi dibanding perairan Laut Maluku. Suhu permukaan tertinggi terukur pada stasiun $11 \& 12$ yaitu $30,21 \& 30,08^{\circ} \mathrm{C}$ dengan nilai salinitas terukur $34,31 \&$ 34,5 psu, tertinggi dibanding nilai suhu dan salinitas terukur di stasiun pengukuran lainnya. Suhu terendah yaitu stasiun $1\left(27,42^{\circ} \mathrm{C}\right)$ dan salinitas permukaan terendah juga terukur pada stasiun 10 (34 psu), kedua stasiun tersebut termasuk dalam kawasan Laut Maluku. Sebaran suhu permukaan di lokasi penelitain berkisar antara $27,75-30^{\circ} \mathrm{C}$ dan salinitas berkisar antara 34,25 $-34,45$ psu. Berdasarkan sirkulasi pola arus permukaan yang dibuat oleh Tomczak \& Godfrey (2003) untuk bulan Agustus (Gambar 2B.) diperoleh penjelasan adanya pengaruh aliran arus permukaan dari Laut Banda dengan karakteristik suhu permukaan terukur lebih dingin di stasiun wilayah perairan Laut Maluku (St.1-10), sedangkan pengaruh arus permukaan dari Samudera Pasifik Ekuatorial dan Laut Sulu yang lebih hangat dengan salinitas tinggi terlihat pada stasiun yang termasuk dalam wilayah perairan Laut Sulawesi (St.1119). Salinitas terendah yang dijumpai pada stasiun 10 , merupakan lokasi pertemuan arus permukaan yang berasal dari Laut Banda dan arus permukaan yang berasal dari wilayah sekitar Kepulauan Aru seperti yang dinyatakan oleh Pranowo (2012) bahwa pada musim peralihan dari musim timur ke musim barat di kawasan perairan Indonesia Timur memiliki pola arus permukaan yang kompleks akibat pertemuan dan percabangan arus yang menghasilkan arus eddy di sekitar wilayah tersebut. Proses mekanik dan fisika seperti transformasi dua massa air permukaan yang berbeda pada lokasi tersebut diduga menghasilkan nilai salinitas yang lebih rendah di banding lokasi 


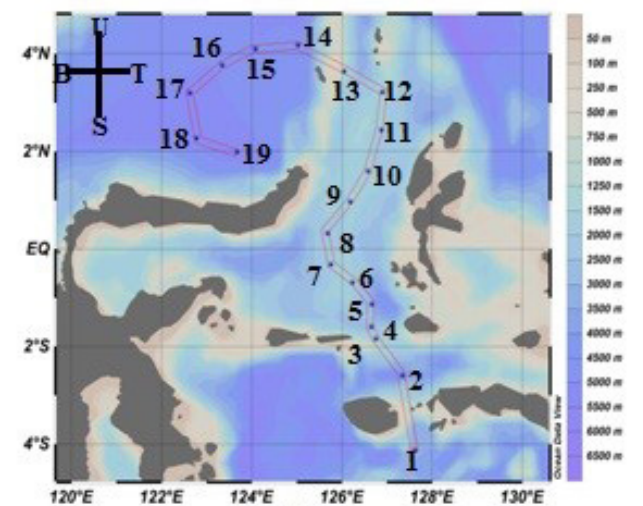

(A)

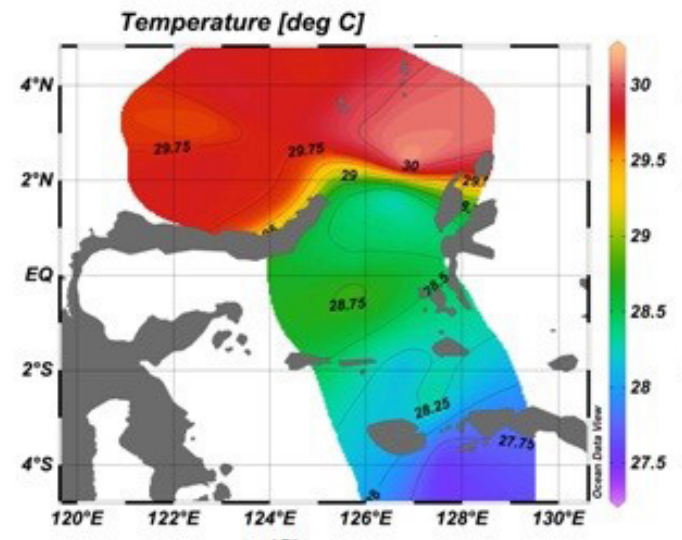

(C)
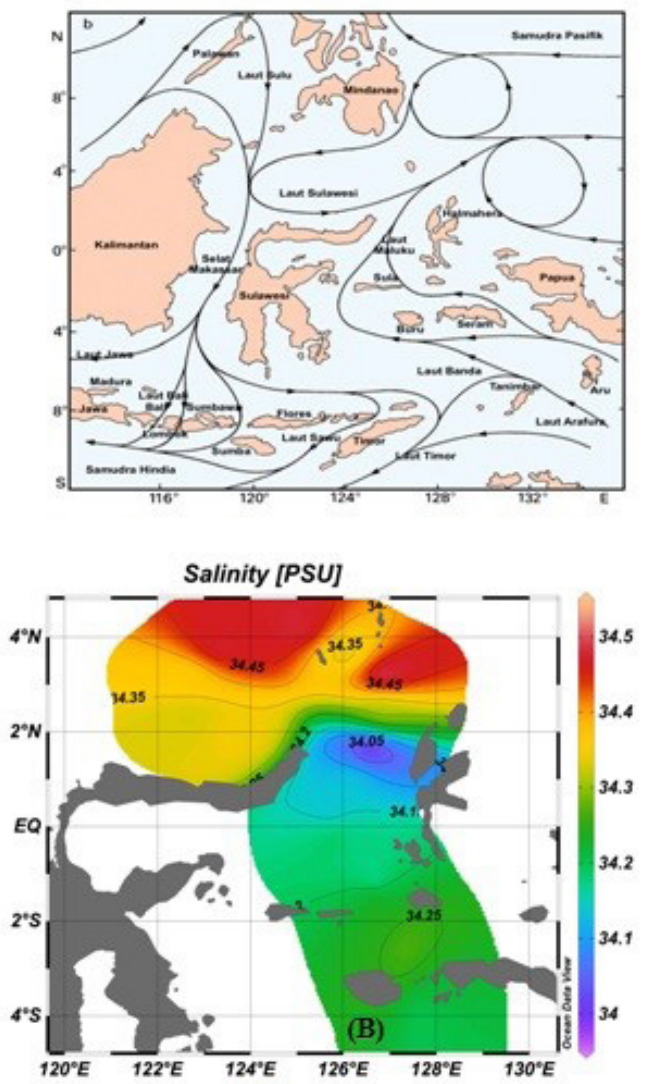

(D)

Gambar 2. Stasiun pengukuran lokasi cruise IJEP 2016 (A), Pola arus permukaan oleh Tomczak \& Godfrey (2003) (B), Suhu permukaan (C) dan Salinitas permukaan (D).

Figure 2. IJEP cruise location measurement station 2016 (A), Surface current pattern by Tomczak \& Godfrey (2003) (B), Surface temperature $(C)$ and Surface salinity (D).

disekitarnya. Laut Sulawesi merupakan pintu masuk dan pertermuan beberapa massa air yang berasal dari Samudera Pasifik dan perairan yang dilewatinya seperti Laut Halmahera.

Profil vertikal suhu dan salinitas terukur pada bulan September 2016 (Gambar 3a\&c, 3b\&d) menunjukkan terbentuknya stratifikasi massa air membentuk tiga lapisan yaitu lapisan massa air permukaan atau lapisan tercampur sempurna (mixed layer), lapisan termoklin dan lapisan dengan suhu dingin (deep layer). Lapisan tercampur sempurna karena memiliki perbedaan nilai suhu dan salinitas hampir seragam (Gambar 3a). Suhu pada lapisan tercampur (mixed layer) berkisar antara $\left(27-30{ }^{\circ} \mathrm{C}\right)$ dan salinitas berkisar antara $34-34,5 \mathrm{psu}$ (Gambar 3b). Hasil yang sama ditemukan oleh (Morey, 1999; Radjawane \& Hadipoetranto, 2014) untuk wilayah perairan Laut Sulawesi, kecuali ketebalan lapisan tercampur terukur pada penelitian ini lebih tipis yaitu 50 meter sedangkan penelitian sebelumnya 75 meter. Penipisan lapisan tercampur jika dibandingkan oleh penelitian sebelumnya, diduga karena waktu pengukuran yang masih termasuk awal musim peralihan sehingga karakteristik lapisan tercampur mencerminkan karakteristik lapisan tercampur (mixed layer) musim timur untuk perairan Indonesia (Wyrtki, 1961).

Lapisan di bawah lapisan tercampur adalan lapisan termoklin yang ditandai adanya penurunan nilai suhu dengan bertambahnya kedalaman dengan nilai perbedaan suhu (delta T) $>0,10 \mathrm{C}$ (Cisewski et.al., 2005). Kisaran nilai suhu perairan lapisan termoklin yang diperoleh pada penelitian ini adalah berkisar antara 10 - 290C pada kedalaman antara sekitar 50 400 meter (Gambar 3c). Ketebalan lapisan termoklin sekitar 350 meter pada lokasi penelitian yang terukur pada bulan September 2015. Penelitian sebelumnya oleh Morey (1999) dan Radjawane \& Hadipoetranto (2014) menyatakan bahwa lapisan termoklin berkisar antara 75 - 350 meter dengan suhu berkisar antara 28 $-24{ }^{\circ} \mathrm{C}$, sehingga pada penelitian ini ditemukan adanya penebalan lapisan termoklin serta peningkatan suhu di lapisan atas termoklin.

Lapisan tercampur (mixed layer) memiliki kisaran

Profil Vertikal Kandungan Oksigen Terlarut dan Fluoresence in vivo sebagai Indikator Keberlangsungan Kehidupan di 

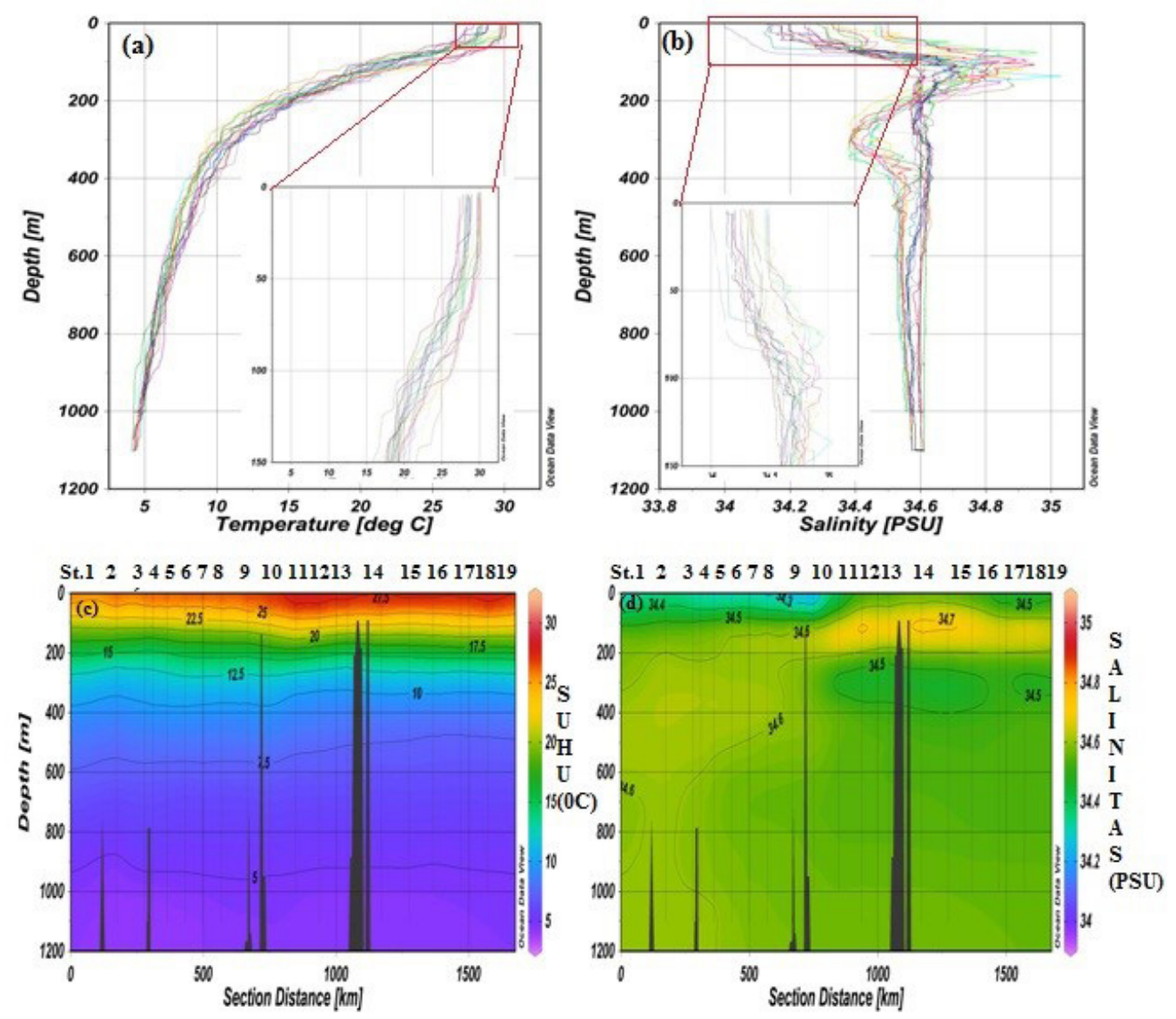

Gambar 3. Profil sebaran vertikal suhu (a \& c), salinitas (b \& d).

Bathymetri menggunakan data set GEBCO grid 6 x 6 menit.

Figure 3. Temperature vertical distribution profile $(a \& c)$, salinity $(b \& d)$. Bathymetry using GEBCO grid data set $6 \times 6$ minutes.

nilai salinitas 34 - 34,5 psu hingga kedalaman sekitar 50 meter, kemudian terjadi peningkatan nilai salinitas terukur dengan bertambahnya kedalaman hingga kedalaman 200 meter (Gambar 3b \& d) atau berada pada lapisan termoklin. Pada lapisan termoklin ditemukan salinitas tertinggi yaitu berkisar antara 34,7 - 34,8 psu pada stasiun yang terletak di kawasan perairan Laut Sulawesi (Gambar 3d). Profil vertikal salinitas pada lokasi penelitian (Laut Sulawesi dan Laut Maluku) setelah kedalaman 200 meter terlihat perbedaan, dimana untuk massa air yang terukur di wilayah perairan Laut Maluku (St.1-10) memiliki nilai salinitas massa air yang menurun (34,6 psu) hingga membentuk nilai yang hampir homogen dengan bertambahnya kedalaman, sedangkan massa air yang terletak di Laut Sulawesi terlihat terjadi penurunan nilai salinitas $(34,4$ psu) hingga kedalaman 300 meter dan selanjutnya meningkat kembali dan membentuk nilai yang homogen di kedalaman 400 meter (Gambar $3 b \quad \& d$ ). Perbedaan ini diduga terkait dengan adanya massa air eksternal yaitu yang berasal dari Samudera Pasifik yang melintasi perairan Indonesia (Indonesian
Throughflow) melalui perairan Laut Sulawesi pada lapisan termoklin. Tomzcak \& Godfrey (2003) menjelaskan bahwa pola arus di lapisan pertengahan menunjukkan bahwa arus intermediate bergerak dari Samudera Pasifik masuk ke wilayah perairan Indonesia melintasi Laut Sulawesi menuju ke Laut Maluku dan Laut Banda. Pola arus yang ditunjukkan oleh Tomzcak \& Godfrey (2003) tersebut memperkuat dugaan akan hasil sebaran nilai suhu dan salinitas secara vertikal yang diperoleh pada lokasi penelitian. Karakteristik massa air yang melintasi perairan Laut Sulawesi dan Laut Maluku pada penelitian ini terlihat dari plot diagram suhu potensial dan salinitas yang disajikan pada Gambar 4.

Hasil penggambaran diagram suhu potensial dan salinitas pada lokasi penelitian (TS diagram) seperti yang diperlihatkan pada Gambar 4A. menunjukkan kesesuaian dengan hasil penelitian yang dilakukan oleh Morey (1999) di Gambar 4B untuk Laut Sulawesi dan Laut Maluku. Hasil pengukuran suhu dan salinitas penelitian ini menunjukkkan adanya 4 tipe massa 

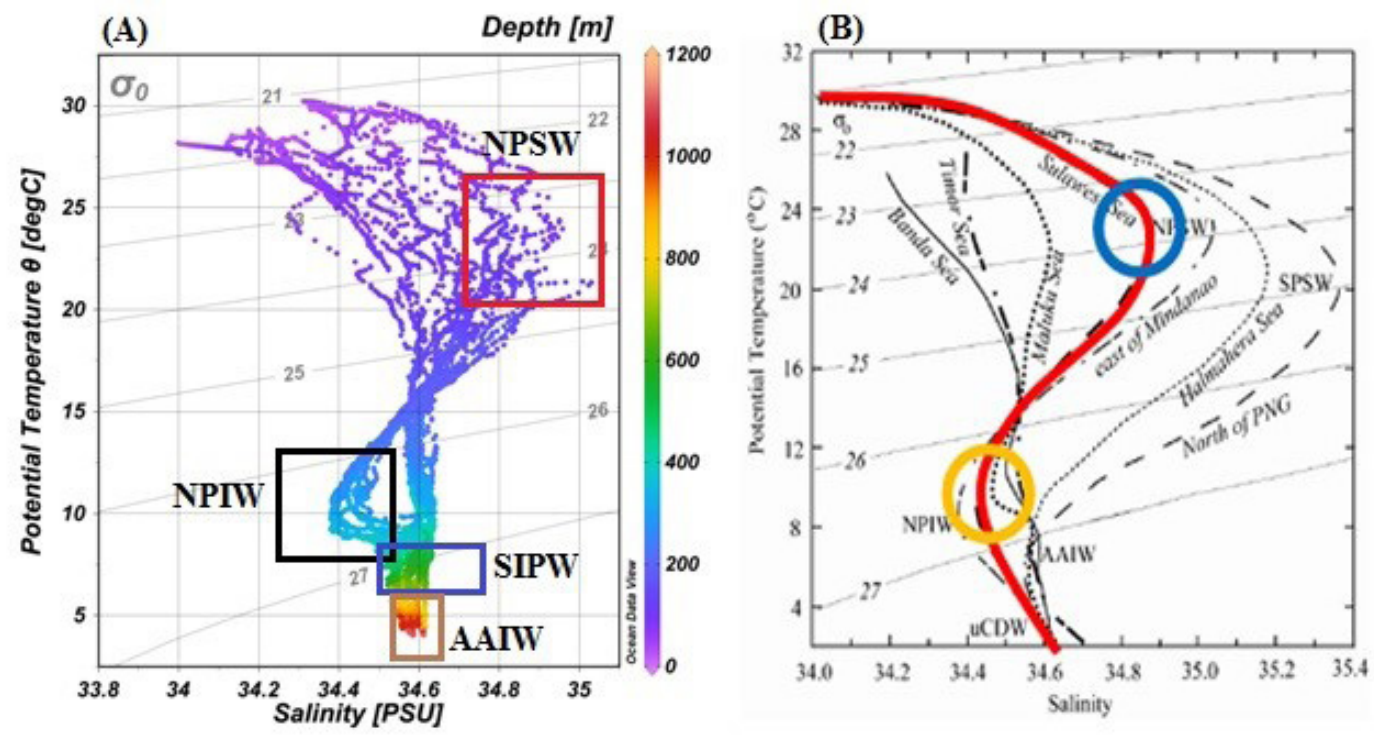

Gambar 4. TS diagram hasil pengukuran cruise IJEP 2016(A) dan TS diagram hasil pengukuran Morey (1999).

Figure 4. TS diagram of IJEP 2016 (A) and TS measurement results measured Morey (1999).

air utama yang melintasi perairan Laut Maluku dan Laut Sulawesi yaitu North Pacific Subtropical Water (NPSW) di kedalaman 100 - 150 meter yang dicirikan oleh suhu perairan $20{ }^{\circ} \mathrm{C}-24{ }^{\circ} \mathrm{C}$ serta salinitas berkisar antara 34,8 - 35,2 psu, North Pacific Intermediate Water (NPIW) di kedalaman 300-600 m yang dicirikan oleh nilai suhu perairan antara $7-11{ }^{\circ} \mathrm{C}$ dan salinitas 34,1 - 34,5 psu, South Pacific Intermediate Water (SPIW) ditemukan pada kedalaman $500-800 \mathrm{~m}$ dengan nilai suhu antara $5-8^{\circ} \mathrm{C}$ dan salinitas $34,45-34,65$ psu, serta Antartic Intermediate Water (AAIW) yang ditemukan pada kedalaman $>750 \mathrm{~m}$ dengan nilai temperatur sekitar $4-7^{\circ} \mathrm{C}$ dan salinitas $34,4-34,7$ psu. Massa air NPSW, NPIW, SPIW, dan AAIW ditunjukkan oleh kotak berwarna merah, hitam, biru dan coklat (Gambar 4A.). Massa air yang melintas di suatu perairan dapat mempengaruhi sifat kimiawi air seperti konsentrasi oksigen terlarut, kandungan nutrient dan mempunyai suhu dan salinitas yang khas.

\section{Distribusi Vertikal Oksigen Terlarut}

Hasil pengukuran konsentrasi oksigen terlarut dengan metode Winkler diperoleh kisaran nilai pada permukaan (distribusi horizontal) serta secara vertikal pada tujuh kedalaman terukur untuk kandungan oksigen terlarut pada lokasi penelitian (Laut Maluku dan Laut Sulawesi). Profil vertikal konsentrasi oksigen terlarut pada lapisan permukaan hingga kedalaman sekitar 50 meter terlihat homogen dengan konsentrasi berkisar antara 5,14 - 7,32 mg/l dengan rerata $6,14 \pm 0,56 \mathrm{mg} / 1$ (Gambar 5A). Hasil pengukuran dengan sensor optik oksigen menunjukkan kisaran yang tidak jauh berbeda yaitu $5,74-6,071 \mathrm{mg} / \mathrm{l}$ dengan rerata $5,857 \pm 0,134$ $\mathrm{mg} / \mathrm{l}$ (Gambar 5B).

Konsentrasi yang terukur pada lapisan tercampur (mixed layer) tertinggi jika dibandingkan dengan lapisan massa air di bawahnya, kondisi ini dijelaskan oleh Millero (2013) bahwa pada lapisan atas (permukaan) merupakan zona fotosintesis dan lapisan yang mendapat kontribusi oksigen langsung dari atmosfer dari peristiwa difusi oksigen dari udara ke permukaan perairan (bubbling). Konsentrasi oksigen setelah kedalaman 50 meter menurun dengan bertambahnya kedalaman hingga kedalaman berkisar antara 200 400 meter kemudian meningkat kembali dikedalaman sekitar 600 meter (Gambar 5B).

Konsentrasi oksigen minimum $(<3,5 \mathrm{mg} / \mathrm{l})$ dijumpai pada kedalaman antara 350 - 400 meter. Lapisan oksigen minimum ini menunjukkan kondisi keseimbangan antara pemanfaatan oksigen (proses oksidasi biologi) dan adveksi kolom air dingin yang kaya akan oksigen (sumber oksigen laut dalam). Peningkatan konsentrasi oksigen di kedalaman lebih dari 600 meter disebabkan karena penenggelaman massa air yang kaya akan oksigen (oksigen mudah larut pada suhu yang dingin) seperti yang dinyatakan oleh Brown et al., (2005) dan Millero (2013) oleh peristiwa adveksi massa air. Peristiwa adveksi massa air di lokasi yang sama juga ditemukan oleh Pranowo (2012). Konsentrasi oksigen terlarut pada lapisan termoklin adalah berkisar antara $3-5,7 \mathrm{mg} / \mathrm{l}$ (Gambar 3A), dimana lokasi perairan Laut Sulawesi memiliki ketebalan lapisan tersebut hingga kedalaman sekitar 380 meter sedangkan perairan Laut

Profil Vertikal Kandungan Oksigen Terlarut dan Fluoresen in vivo sebagai Indikator Keberlangsungan Kehidupan di Perairan Laut Maluku dan Laut Sulawesi - Iis Triyulianti, Indra Hermawan, Agung Yunanto, Novia Arinda Pradisty, 

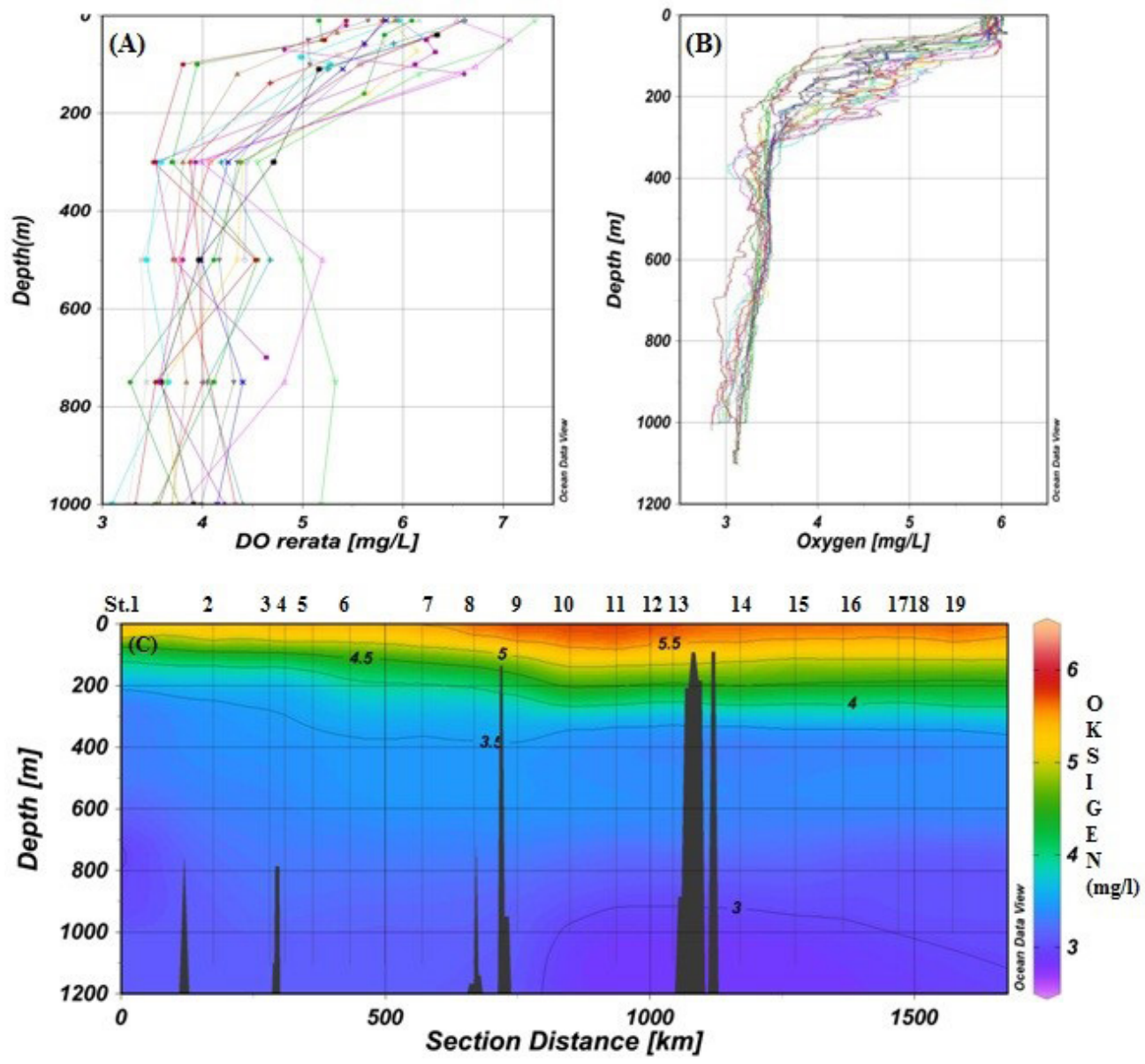

Gambar 5. Profil vertikal oksigen terlarut hasil pengukuran metode titrimetrik (A) sensor oksigen pada CTD (B) dan section vertikal (C) Batimetri menggunakan data set GEBCO grid 6 x 6 menit.

Figure 5. The vertical profile of dissolved oxygen results from measurement of titrimetric method (A) oxygen sensor on $C T D(B)$ and vertical section (C) Bathymetry using data set GEBCO grid $6 \times 6$ minutes.

Maluku hanya sampai kedalaman $<200$ meter (St.16). Penurunan konsentrasi oksigen setelah lapisan tercampur menunjukkan bahwa laju pemanfaatan oksigen melalui proses respirasi lebih tinggi dibanding laju produksinya (fotosintesis) karena di bawah lapisan tercampur (mixed layer depth) terjadi akumulasi bahan organik dari sisa pakan dan feses organisme perairan atau proses regenerasi bahan organik serta ketersediaan cahaya yang masuk ke kolom dalam perairan berkurang (Sigman et al., 2010). Cahaya merupakan salah satu faktor pembatas yang mempengaruhi proses fotosintesis oleh fitoplankton, sehingga penurunan intensitas cahaya (Photosintetic Active Reaction atau PAR) pada kolom perairan akan menurunkan laju fotosintesis dan berkurangnya oksigen yang dilepaskan ke kolom perairan (oksigen terlarut). Distribusi spasial (horisontal) konsentrasi oksigen terlarut menunjukkan bahwa lokasi perairan Laut Sulawesi lebih tinggi konsentrasinya dibanding Laut Maluku. Perbedaan konsentrasi ini diduga karena pengaruh letak Laut Sulawesi yang berhadapan dan dipengaruhi langsung oleh arus massa air dari Samudera Pasifik.

Laut Sulawesi dan Laut Maluku merupakan kawasan perairan yang dilintasi oleh arus lintas Inodnesia (ARLINDO) yang berasal dari Samudera Pasifik, seperti yang diperlihatkan pada Gambar 4 menunjukkkan tipe massa air dari Samudera Pasifik yang melintasi di kawasan tersebut. Hasil penelitian Ayers et al. (2014) dengan mengunakan pemodelan numerik menunjukkan adanya pengaruh masukan massa air yang meilntasi perairan Indonesia menuju Samudera Hindia pada proses regenerasi nutrient sehingga terbentuk produksi baru (new production) serta mempengaruhi proses siklus biogeokimiawi pada lokasi tersebut. Peneliti sebelumnya yaitu Wyrtky (1961) telah menunjukkan adanya pengaruh karakteristik massa air Samudera Pasifik Utara terhadap konsentrasi oksigen, dimana dari hasil penelitiannya diketahui ciri massa air pada lapisan salinitas termoklin atas yang maksimum diperoleh nilai konsentrasi oksigen terlarut atau dissolved oxygen (DO) yang relatif lebih tinggi yaitu berkisar antara 
3,7 - 4,6 mg/l untuk massa air dari North Subtropical Lower Water pada kisaran suhu $20-24^{\circ} \mathrm{C}$ dan salinitas $34,8-35,2$ psu. Kisaran nilai tersebut terlihat juga terlihat pada hasil pengukuran di wilayah perairan Laut Sulawesi dan Laut Maluku dengan konsentrasi lebih tinggi yaitu berkisar antara 4 - $5 \mathrm{mg} / \mathrm{l}$.

Massa air samudera pasifik memiliki profil vertikal konsentrasi oksigen terlarut berkisar antara $4-8 \mathrm{mg} / \mathrm{l}$ dari permukaan hingga kedalaman sekitar 400 meter (Brown et al., 2005 dan Millero, 2013). Fenomena ini menunjukkan bahwa pergerakan massa air global melintasi perairan Indonesia mempengaruhi konsentrasi oksigen terlarut di wilayah perairan Indonesia, khususnya yang menjadi perlintasan massa air tersebut seperti Laut Sulawesi dan Laut Maluku. Hasil penelitian ini menunjukkan karakteristik profil vertikal konsentrasi oksigen terlarut di perairan Laut Sulawesi dan Laut Maluku hingga kedalaman sekitar 1000 meter, terstratifikasi berdasarkan nilai konsentrasi oksigennya pada suhu dan salinitas terukur dan terindikasi menjadi ciri khas untuk pengukuran di musim peralihan (September).

Lapisan permukaan hingga kedalaman sekitar 50 meter dengan suhu berkisar antara $29-30^{\circ} \mathrm{C}$ dan salinitas berkisar antara 34 - 34,5 psu merupakan lapisan homogen oksigen terlarut dengan konsentrasi sebesar 5-6 mg/L (Gambar 6A \& B). Konsentrasi oksigen terlarut pada lapisan termoklin dengan suhu berkisar antara $29-10{ }^{\circ} \mathrm{C}$ dan salinitas berkisar antara 34,4 - 35,2 psu pada kedalaman sekitar 350 meter adalah berkisar anatar 3,8 -6 mg/l, dan pada lapisan dingin (deep water) yaitu lapisan di bawah lapisan termoklin di kedalaman lebih dari 400 meter ditemukan karakteristik terjadinya peningkatan konsentrasi oksigen hingga kedalaman sekitar 600 meter. Konsentrasi pada lapisan tersebut berkisar antara 3 - 3,5 mg/l, setelah kedalaman 600 meter atau lapisan dengan karakteristik suhu $<5^{\circ} \mathrm{C}$ dan salinitas berkisar antara 34,5 - 34,6 psu, konsentrasi oksigen terlihat kembali menurun hingga membentuk profil konsentrasi oksigen yang stabil di nilai sekitar 2,7 - 3,2 mg/l hingga kedalaman maksimal pengukuran yaitu 1000 meter (Gambar 6 A \& B).

Karakteristik profil vertikal oksigen terlarut yang dijumpai di wilayah perairan Laut Sulawesi dan Laut Maluku dapat dijadikan indikator biologi bagi penyebaran organisme laut baik mikro maupun makro, karena oksigen merupakan kebutuhan dasar organisme hidup serta fugasitasnya pada kolom perairan bersama dengan karbon dioksida (CO2) menjadi dua kunci penting dalam variabel termodinamika untuk menggambarkan kondisi fisiologis organisme aerob laut (Ortner \& Farrell, 2008 ;Hofmann et al., 2011; Seibel et al., 2012 dan Cocco et al., 2013). Keterkaitan kondisi oksigen terlarut dengan indikasi keberlangsunagn kehidupan diperkuat dengan kenyataan bahwa keanekaragam biota atau hayati laut Indonesia di wilayah perairan Indonesia timur menjadi bagian mega biodiversitas kekayaan laut Indonesia (Veron, 2000), tidak terkecuali wilayah perairan Laut Maluku dan Laut Sulawesi yang terlihat peranannya sebagai salah satu sentra penangkapan ikan pelagis.
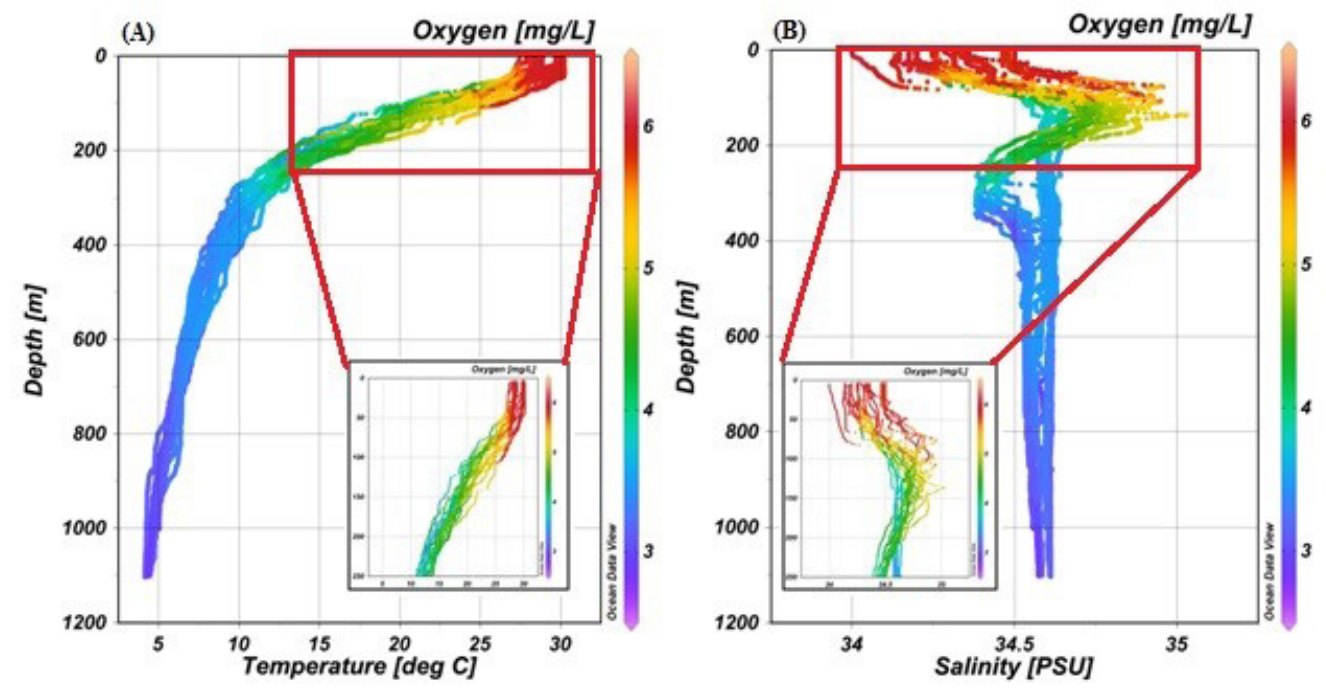

Gambar 6. Profil vertikal konsentrasi oksigen terlarut, dan suhu terukur (A) dan salinitas terukur (B).

Figure 6. Vertical profile of dissolved oxygen concentration, and measured temperature (A) and measured salinity (B).

Profil Vertikal Kandungan Oksigen Terlarut dan Fluoresen in vivo sebagai Indikator Keberlangsungan Kehidupan di Perairan Laut Maluku dan Laut Sulawesi - Iis Triyulianti, Indra Hermawan, Agung Yunanto, Novia Arinda Pradisty, Aditya Chandra Raymonza, Fikrul Islamy dan Nadia Christa Magdalena 


\section{Distribusi vertikal fluoresen in vivo}

Indikasi tingginya keanekaragaman hayati perairan Indonesia menunjukkan bahwa ekosistem perairan menyediakan daya dukung untuk menjaga keberlangsungan kehidupan biota di wilayah perairan tersebut. Daya dukung ekosistem wilayah perairan Laut Sulawesi dan Laut Maluku, tidak hanya terlihat dari konsentrasi oksigen terlarut, tetapi dapat juga dari kelimpahan dan biomassa fitoplankton sebagai produsen senyawa oksigen (produsen primer) dan produsen dalam trophic level yang mencerminkan produktivitas biologi wilayah tersebut. Konsentrasi biomassa fitoplankton pada penelitian ini terukur dengan metode fluorometrik atau menggunakan sensor optik fluoremeter pada panjang gelombang $685 \mathrm{~nm}$ (Lorenzon, 1966). Estimasi konsentrasi klorofil-a dengan menggunakan fluoresen in vivo telah banyak dilakuan dekade terakhir ini untuk penelitian ekosistem perairan (Chekalyuk et al., 2008 ; Chekalyuk et al., 2011).
Pengukuran biomassa fitoplankton dengan sensor fluorometer dilakukan untuk mengetahui profil kandungan klorofil-a perairan Laut Maluku dan Laut Sulawesi hingga kedalaman maksimum pengukuran yaitu 1000 meter. Profil vertikal fluoresen in vivo pada lokasi penelitian dapat digunakan untuk menggambarkan kuantitas (biomassa) komunitas fitoplankton yang berperan sebagai produsen primer pada ekosistem perairan. Pengukuran dilakukan secara in situ (terukur pada kedalaman dan suhu tertentu) secara kontinyu pada saat casting CTD (pengukuran parameter fisika dan kimia yang terintegrasi pada CTD). Hasil pengukuran fluoresen in vivo di lokasi penelitian memperlihatkan kembali stratifikasi berdasarkan lapisan kedalaman massa air dengan karakteristik suhu dan salinitas tertentu. Profil vertikal fluoresen in vivo terukur pada lokasi penelitian terlihat pada Gambar 7 dengan karakteristik yang berbeda dari oksigen terlarut.

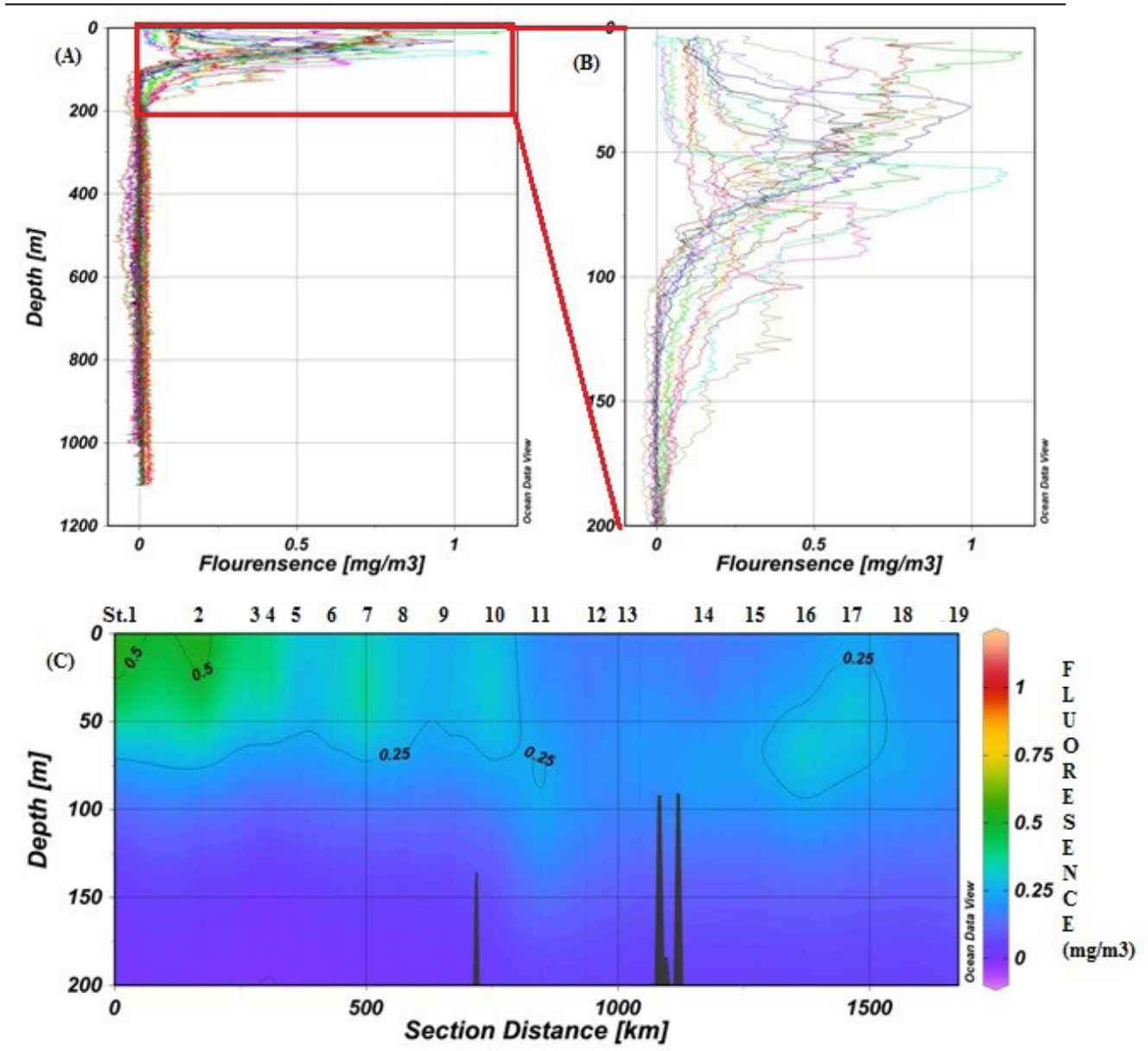

Gambar 7. Profil vertikal fluorescence in vivo kedalaman $1000 \mathrm{~m}(\mathrm{~A}), 200 \mathrm{~m}(\mathrm{~B})$ dan Section vertikal (C). Batimetri menggunakan data set GEBCO grid 6 × 6 menit.

Figure 7. Vertical fluorescence profile in vivo depth $1000 \mathrm{~m}$ (A), $200 \mathrm{~m}$ (B) and vertical Section (C). Bathymetry using GEBCO grid data set $6 \times 6$ arcminutes.

JURNAL KELAUTAN NASIONAL, Vol. 12, No 2, Agustus 2017, Hal. 59-71 
Konsentrasi fluoresen in vivo pada lapisan permukaan memiliki nilai berkisar antara $0,1-1,5 \mathrm{mg} / \mathrm{m}^{3}$, dengan karakteristik terbentuknya lapisan maksimum konsentrasi fluoresen in vivo di kedalaman berkisar antara 50 - 150 meter. Kondisi ini memperlihatkan bahwa pada lapisan homogen suhu dan salinitas serta oksigen (mixed layer), konsentrasi fluoresen in vivo meningkat dengan bertambahnya kedalaman hingga kedalaman konsentrasi fluoresen in vivo maksimum (50 - 150 meter) seperti yang ditunjukkan oleh Gambar 7 A\&B. Distribusi spasial konsentrasi fluoresen in vivo pada lokasi penelitian menunjukkan bahwa lokasi perairan Laut Maluku memiliki konsentrasi fluoresen in vivo lebih tinggi dibanding Laut Sulawesi. Kondisi sebaliknya untuk distribusi horisontal oksigen terlarut dimana, perairan Laut Sulawesi lebih tinggi konsentrasinya. Konsentrasi fluoresen in vivo lebih tinggi di perairan Laut Maluku diduga terkait dengan pengaruh proses upwelling di perairan Laut Banda yang dibangkitkan oleh energi angin monsun timur (Easterlies) pada musim timur (Pranowo, 2012) serta energi pasang surut internal (internal tides) seperti yang disebutkan oleh Gordon et al. (2001) dan Pranowo et al. (2011) yang lebih khusus menyebutkan bahwa tipe pasang surut di wilayah utara Laut Timor adalah tipe campuran prevailing semidiurnal. Dugaan ini diperkuat dengan memperhatikan karakteristik massa air permukaan perairan Laut Maluku pada musim timur dipengaruhi massa air internal dari perairan Laut Banda dan Laut sekitar Halmahera (Tomzcak \& Godfrey, 2003). Konsentrasi klorofil-a yang terdeskripsikan dari nilai fluoresen in vivo yang diperoleh pada lapisan permukaan hingga kedalaman $\sim 150$ meter sebesar $0,1-1,5 \mathrm{mg} / \mathrm{m}^{3}\left(>0,2 \mathrm{mg} / \mathrm{m}^{3}\right)$ di

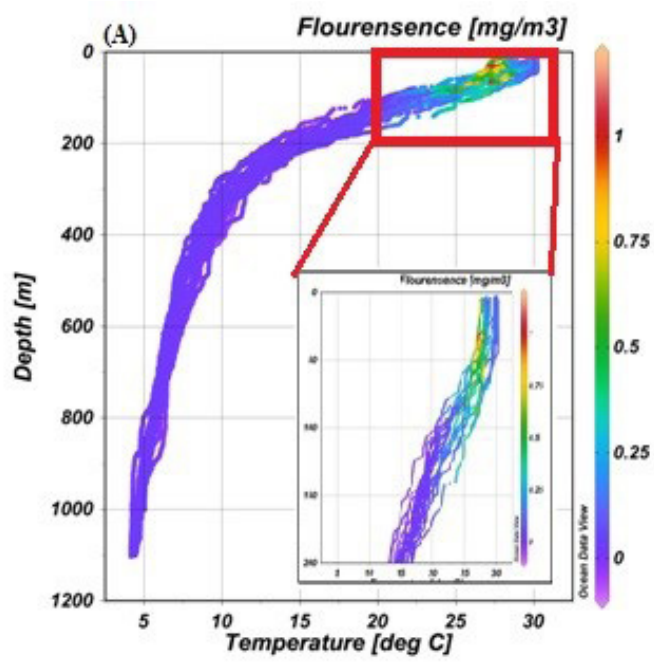

wilayah perairan Laut Sulawesi dan Laut Maluku mengindikasikan keberadaan biomassa fitoplankton yang cukup tinggi menjaga kelangsungan kondisi perikanan komersial (Gower, 1972).

Fluoresen in vivo terukur merupakan representasi kemampuan klorofil-a menyerap energi photon (energi cahaya) dan merefleksikannya (emit) pada panjang gelombang tertentu (Lorenzon, 1966). Fakta ini menyebabkan konsentrasi fluoresen in vivo terukur membutuhkan kalibrasi dengan pengukuran klorofil-a dengan melakukan ekstraksi menggunakan aceton. Fluoresen in vivo digunakan sebagai salah satu metode untuk melakukan estimasi biomassa fitoplankton melalui konsentrasi klorofil-a, karena nilainya menggambarkan signal energi yang hilang pada total komunitas fitoplankton serta dapat mengestimasi pertumbuhan fitoplankton (Mackey et al., 2000) serta untuk pengukuran konsentrasi klorofil-a di laut lepas yang umumnya rendah dengan metode fluorometrik lebih disukai karena memiliki sensivitas yang tinggi (Holm-Hansen et al., 1965).

Suhu terukur pada lapisan klorofil-a fluoresen maksimum adalah $25-28^{\circ} \mathrm{C}$ dengan salinitas $34-34,8$ psu (Gambar 8 A\&B) menunjukkan bahwa intensitas panjang gelombang yang diserap oleh klorofil-a untuk proses fotosintesis maksimum pada kedalaman 50 150 meter dengan suhu berkisar $25-28^{\circ} \mathrm{C}$. Lorenzen (1966) menyebutkan bahwa setiap perubahan $1^{\circ} \mathrm{C}$ suhu perairan menghasilkan perubahan nilai fluoresen sebesar 1,4\%, pada kondisi suhu perairan berkisar antara $0-35^{\circ} \mathrm{C}$. Fluoresen in vivo terukur didapati hanya kolom perairan diatas 200 meter (Gambar 7B \&

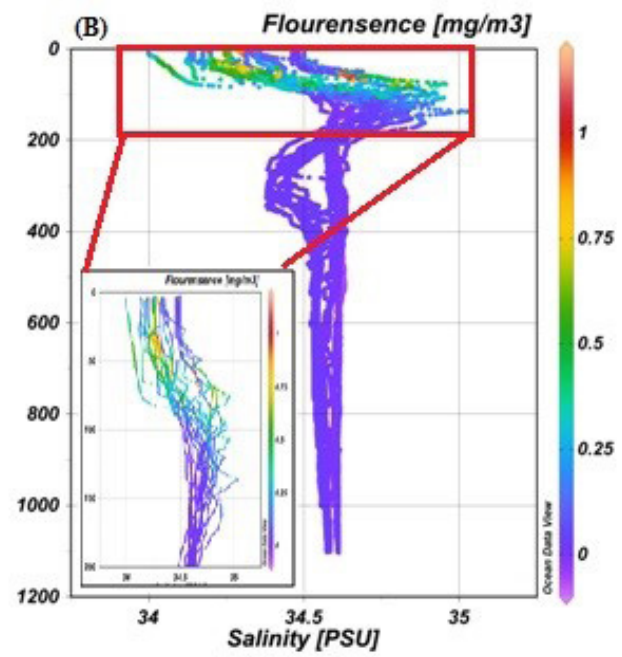

Gambar 8. Profil vertikal fluorosence pada sebaran suhu (A) dan salinitas (B). Figure 8. Vertical fluorosence profile at temperature distribution (A) and salinity (B).

Profil Vertikal Kandungan Oksigen Terlarut dan Fluoresen in vivo sebagai Indikator Keberlangsungan Kehidupan di 
Gambar 8) menunjukkan sebaran atau profil vertikal komunitas fitoplankton serta kedalaman produktivitas primer hanya sampai kedalaman kurang dari 200 meter untuk lokasi penelitian (Laut Sulawesi dan Laut Maluku).

Sebaran vertikal nilai fluoresen in vivo yang diperoleh dari pengukuran klorofil-a pada penelitian ini juga menunjukkan bahwa konsentrasi oksigen terukur dan bersumber dari peristiwa fotosintesis di perairan Laut Maluku dan Laut Sulawesi terindikasi berada pada lapisan tercampur (mixed layer) serta 100 meter di bawah lapisan tercampur tersebut. Keberadaan oksigen terlarut pada kolom atau lapisan massa air di bawah kedalaman 200 meter diindikasikan berasal dari peristiwa adveksi massa air kolom air dingin (singking cold water) serta hasil proses transformasi massa air yang berasal dari Samudera Pasifik.

\section{KESIMPULAN DAN SARAN}

Berdasarkan hasil analisis spasial (vertikal dan horizontal) hasil pengukuran oksigen terlarut dan fluoresen in vivo selama pelayaran ilmiah (cruise) Indeso Joint Expeditions (IJEP) 2016 menunjukkan bahwa wilayah perairan Laut Sulawesi memiliki konsentrasi oksigen terlarut lebih tinggi baik secara vertikal dan horizontal dibanding Laut Maluku di musim peralihan (September). Kondisi sebaliknya terjadi pada konsentrasi fluoresen in vivo yang ditemui lebih tinggi di wilayah perairan Laut Maluku baik secara vertikal maupun horizontal.

Indikasi adanya pengaruh lintasan massa air global dari Samudera Pasifik Utara terhadap konsentrasi oksigen pada perairan Laut Sulawesi pada lapisan tercampur (mixed layer) dan lapisan termoklin terlihat pada hasil penelitian ini. Pengaruh massa air internal permukaan yang berasal dari Laut Banda terindikasi pada tingginya konsentrasi fluoresen in vivo terukur pada musim peralihan.

Profil vertikal konsentrasi oksigen terlarut dan fluoresen in vivo perairan memberikan indikasi kemampuan atau daya dukung ekosistem yang cukup baik untuk menjaga kelangsungan hidup organism perairan di wilayah perairan Laut Sulawesi dan Laut Maluku.

\section{UCAPAN TERIMA KASIH}

Artikel ini telah dipresentasikan pada acara Gelar Riset dan Inovasi Teknologi Kelautan dan Perikanan pada tanggal 24-27 Oktober 2017. Acara tersebut diinisiasi dan dikoordinir oleh Badan Riset dan Sumber Daya Manusia, Kementrian Kelautan dan Perikanan Republik Indonesia. Kegiatan pelayaran ilmiah (IJEP cruise 2016) terselenggara berkat dukungan dan kerjasama antara Balai Riset dan Observasi Laut, Pusat Riset Kelautan, BRSDM-Kementrian Kelautan dan Perikanan serta INDESO project. Ucapan terima kasih juga, kami ucapkan untuk para peneliti P2O-LIPI dan seluruh kru Baruna Jaya VIII Research Vessel serta peserta pelayaran ilmiah IJEP cruise 2016. Terakhir, penulis mengucapkan terimakasih kepada reviewer anonim yang telah memberikan saran berarti bagi perbaikan tulisan ini.

\section{DAFTAR PUSTAKA}

Ayers, J. M., P. G. Strutton., V. J. Coles., R. R. Hood., R. J. Matear. (2014). Indonesian throughflow nutrient fluxes and theirpotential impact on Indian Ocean productivity. Geophys. Res. Lett., 41, 5060-5067, doi:10.1002/2014GL060593

Brown, E., Colling. A., James. R., Park. D., Philips. J., Rothery. D., \& Wright. J. (2005). Marine Biogeochemistry Cycles (2nd edition). The Open University, Milton Keynes, England.

Carritt, D.E., \& J.H Carpenter. (1966). Comparison and evaluation of currently em-ployed modifications of the Winkler method for determining dissolved oxygenin seawater: a NASCO report. J. Mar. Res. 24, 286-318

Chekalyuk, A., \& Hafez. M. A. (2008). Advanced laserfluorometry of natural aquatic environments. Limnol. Oceanogr. Methods 6, 59

Chekalyuk, A., \& Hafez. M. A. (2011). Photo-physiological variability in phytoplankton chlorophyll fluorescence and assessment of chlorophyll concentration. Opt. Exp. 19, 22643-22658

Cisewski, B., Strass. V. H., \& Prandke. H. (2005). UpperOcean vertical mixing in the antaratic. Deep Sea Research Part II : Topical Studies in Oceanography, (52) : 1087-1108.

Cocco, V., Joos. F., Steinacher. M., Fr “ olicher. T. L, Bopp. L., Dunne. J., Gehlen. M., Heinze. C., Orr. J., Oschlies. A., Schneider. B., Segschneider. J., \& Tjiputra. J. (2013). Oxygen and Indicators of Stress for Marine Life in Multi Model Global Warming Projection. Biogeosciences 10 : 1849-1868.

Falkowsky, P., Scholes. R. J., Boyle. E., Canadell. J., CanPeld. D., Elser. J., Gruber. N., Hibbard. K., Hogberg. P., Linder. S., Mackenzie. F. T., Moore III. B., Pedersen. T., Rosenthal. Y., Seitzinger. S., Smetacek. V., \& Steffen. W. (2000). The Global Carbon Cycle: A Test of Our Knowledge of Earth as a System. An Review : Climate Change. Science 290: 291-295. 
Falkowski, P. G., \& Raven. J.A2007. Aquatic Photosynthesis. Blackwell Science Publisher, Malden Massachussette, USA. 375p.

Gower, J. F. R. (1972). A survey of the uses of remote sensing from aircraft and satellites in oceanography and hydrography. Pac.Mar.Sci.Rep.Inst. Ocean.Sci., Sidney, B.C., Can., (72-3).

Gordon, A. L., \& Susanto. R. D. (2001). Banda Sea Sea surface Layer Divergence. Ocean Dynamics : 52, 2-10.

Hofmann, A. F., Peltzer, E. T., Walz, P. M., \& Brewer, P. G. (2011). Hypoxia by degrees: Establishing definitions for a changing ocean, Deep-Sea Res. I, 58, 12121226, doi:10.1016/j.dsr.2011.09.004,

Holm-Hansen, O., Lorenzen, C. J. R., Holmes, W., \& Strickland, J. D. H (1965). Fluorometric determination of chlorophyll. Journal du Conseil, Conseil Permanent International pour Explorer de la Mer 30, 3-15.

Keeling, R.F., Kortzinger, A., \& Gruber, N. (2010). Ocean deoxygenation in a warming world. Annu. Rev. Mar. Sci., 199-229 (Palo Alto).

Lorenzen, C. J. (1966). A method for the continous measurement of in vivo chlorophyll concentration. Deep-Sea Research 13, 223-227.

Mackey, D. J., Blanchot, Higgins, H. W \& Neveux, J. (2000). PhytoplanktonAbundance and community structure in the equatorial pacific. Deep Sea Research Part II. 44 (9-10): 1951-1978.

Millero, F. J. (2013). Chemical Oceanography 4th ed. CRC Press by Taylor and Francis Group. Boca Raton, FL. $571 \mathrm{pp}$.

Morey, S.L., Shriver, J.F., \& O'brien, J.J. (1999). Effects of Halmahera on The Indonesian Throughflow. J. Geophys. Res., 104(C10):23281-23296.

Paulmier, A., Ruiz-Pino, D., \& Garc, on, V. (2011). $\mathrm{CO}_{2}$ maximum inthe oxygen minimum zone (OMZ), Biogeosciences, 8, 239-252, doi:10.5194/bg-8-239

Pearson, T.H., \& Rosenberg, R (1978). Macrobenthic succession in relation to organic enrichment and pollution of the marine environment. Oceanogr. Mar. Biol.Annu. Rev. 16, 229-311.

Portner, H. O., \& Farrell, A. P. (2008). Physiology and climate change,Science, 322, 690-692, doi:10.1126/ science.1163156, 2008.

Pranowo, W. S., \& Wirasantosa, S. (2011). Tides Regimes of Arafura and Timor Sea. Marine Research Indonesia, $36(1): 21-28$.

Pranowo, W. S. (2012). Dinamika Upwelling dan Downwelling di Laut Arafuru dan Timor. Widyariset, 15(2): $415-423$.

Radjawane, I. M., \& Hadipoetranto, P. P. (2014). Karakteristik massa air di percabangan arus lintas Indonesia perai-ran Sangihe Talaud menggunakan data index satal 2010. J. Ilmu dan Teknlogi Kelautan Tropis, 6(2):525-536.

Seibel, B. A., Oschlies, A., \& Childress, J. J. (2012). The real limits to marine life: a further critique of the
Respiration Index, Biogeo-sciences Discuss., 9, 16521-16532, 10.5194/bgd-9 16521.

Sigman, D.M., et al., 2010. The polar ocean and glacial cycles in atmospheric $\mathrm{CO}_{2}$ concentration. Nature 466, 47-55.

Stramma, L., Johnson, G. C., Sprintall, J., \& Mohrholz, V. (2008). Expanding oxygen minimum zones in the tropical oceans, Science,320, 655-658, doi:10.1126/ science. 1153847.

Suman, A., Wudianto., Sumiono. B., Irianto, H. E., Badrudin., \& Amri, K. (2014). Potensi dan Tingkat Pemanfaatan Ikan di Wilayah pengelolaan Perikanan, Republic Indonesia. Balai Penelitian Perikanan laut. P2Perikanan \& Kelautan. BALITBANG -KP. Kementerian Kelautan dan Perikanan, republic Indonesia.

Tomzchak, M. \& Godfrey, J. S. (2003). Regional Oceanography. : an Introduction (2nd edition). Daya Publishing House, New Delhi.

Veron, J.E.N. (2000). Corals of the World. Volumes 1-3 Australian Institute of Marine Science, Townsville, Australia.

Wyrtki, K. (1961). Physical Oceanography of Southeast Asian Waters. Naga Report, Volume 2. The University of California Scripps Institution of Oceanography: La Jolla California. United States of America. 225p.

Profil Vertikal Kandungan Oksigen Terlarut dan Fluoresen in vivo sebagai Indikator Keberlangsungan Kehidupan di

Perairan Laut Maluku dan Laut Sulawesi - Iis Triyulianti, Indra Hermawan, Agung Yunanto, Novia Arinda Pradisty, Aditya Chandra Raymonza, Fikrul Islamy dan Nadia Christa Magdalena 